\title{
Factors Associated with National Health Insurance Coverage
}

\section{in Indonesia [version 1; peer review: 1 approved, 1 approved}

\section{with reservations]}

\author{
Tintin Sukartini (D1, Hidayat Arifin (D2, Yulia Kurniawati2, Rifky Octavia Pradipta1, \\ Nursalam Nursalam (iD), Joel Rey Ugsang Acob (iD) 3
}

${ }^{1}$ Department of Advanced Nursing, Faculty of Nursing, Universitas Airlangga, Surabaya, Indonesia

${ }^{2}$ Department of Medical-Surgical Nursing, Faculty of Nursing, Universitas Padjadjaran, Bandung, Indonesia

${ }^{3}$ Visayas State University, City of Baybay, Philippines

\author{
V1 First published: $14 \mathrm{Jul}$ 2021, 10:563 \\ https://doi.org/10.12688/f1000research.53672.1 \\ Latest published: 14 Sep 2022, 10:563 \\ https://doi.org/10.12688/f1000research.53672.2
}

\section{Abstract}

Background: The National Health Insurance (NHI) program is the Indonesian government's national health program. However, health insurance coverage has not been maximized. This study aims to analyze the factors associated with health insurance coverage in Indonesia.

Methods: Cross-sectional data were obtained from the Indonesian Demographic and Health Survey 2017. A total of 39,580 respondents were selected using two-stage stratified cluster sampling. The data come from the DHS Questionnaire Phase 7. The variables include age, education level, wealth quintiles, residence, the number of children who are alive, marital status, current employment status, earnings, and health insurance status. The data were analyzed using chi-squared and binary logistic analyses.

Results: The prevalence of health

insurance coverage in the Indonesian population is $62.3 \%$.

Respondent age [AOR=0.875; 95\% CI=0.763-0.967], education level [AOR $=0.437 ; 95 \% \mathrm{CI}=0.410-0.466]$, wealth quintile $[\mathrm{AOR}=0.762 ; 95 \%$ $\mathrm{CI}=0.713-0.815]$, residence $[\mathrm{AOR}=0.762 ; 95 \% \mathrm{CI}=0.713-0.815]$, marital status $[A O R=0.718 ; 95 \% \mathrm{CI}=0.625-0.825]$ and earnings $[\mathrm{AOR}=1.245$; 95\% CI=1.177-1.316] are related to health insurance coverage. However, the number of children who are alive and respondents who were currently working were not significantly related to health insurance coverage in Indonesia.

Conclusion: The government needs to pay attention to the characteristics and demographic conditions of the Indonesian population to be able to achieve maximum health insurance coverage. Maximum coverage through the provision of appropriate information should be promoted.

\section{Open Peer Review}

Approval Status

1 2

version 2

(revision)

14 Sep 2022

version 1

14 Jul 2021

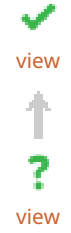

1. Linlin Lindayani ${ }^{-D}$, Sekolah Tinggi Ilmu Keperawatan PPNI Jawa Barat, Bandung, Indonesia

\section{Mohd Khairul Zul Hasymi Bin Firdaus,}

International Islamic University Malaysia,

Pahang, Malaysia

Any reports and responses or comments on the article can be found at the end of the article. 
Keywords

health insurance; health policy; demographic health survey; Indonesia

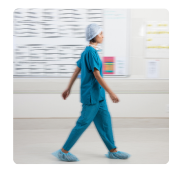

This article is included in the Health Services

gateway.

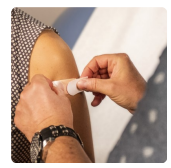

This article is included in the Sociology of

Health gateway.

Corresponding author: Nursalam Nursalam (nursalam@fkp.unair.ac.id)

Author roles: Sukartini T: Conceptualization, Formal Analysis, Methodology, Writing - Original Draft Preparation, Writing - Review \& Editing; Arifin H: Conceptualization, Formal Analysis, Methodology, Software, Writing - Original Draft Preparation, Writing - Review \& Editing; Kurniawati Y: Conceptualization, Methodology, Writing - Review \& Editing; Pradipta RO: Conceptualization, Formal Analysis, Methodology, Validation, Writing - Review \& Editing; Nursalam N: Conceptualization, Formal Analysis, Methodology, Writing - Original Draft Preparation, Writing - Review \& Editing; Acob JRU: Conceptualization, Methodology, Writing - Review \& Editing

Competing interests: No competing interests were disclosed.

Grant information: The author(s) declared that no grants were involved in supporting this work.

Copyright: ( $) 2021$ Sukartini T et al. This is an open access article distributed under the terms of the Creative Commons Attribution License, which permits unrestricted use, distribution, and reproduction in any medium, provided the original work is properly cited. The author(s) is/are employees of the US Government and therefore domestic copyright protection in USA does not apply to this work. The work may be protected under the copyright laws of other jurisdictions when used in those jurisdictions.

How to cite this article: Sukartini T, Arifin $\mathrm{H}$, Kurniawati $Y$ et al. Factors Associated with National Health Insurance Coverage in Indonesia [version 1; peer review: 1 approved, 1 approved with reservations] F1000Research 2021, 10:563 https://doi.org/10.12688/f1000research.53672.1

First published: 14 Jul 2021, 10:563 https://doi.org/10.12688/f1000research.53672.1 


\section{Introduction}

The National Health Insurance (NHI) is the Indonesian government's program which provides people with the chance to access health services for health promotion, illness prevention, illness treatment, and rehabilitation at an affordable cost. ${ }^{1,2}$ The Indonesian government started the NHI program in 2004, provided in the form of the Social Security Administrator (SSA) which is divided into two sectors namely the Social Security Administrator for Health (SSAH) and the Social Security Administrator for Employment (SSAE). However, the full coverage target was not achieved in 2017. ${ }^{3}$ Another problem remains, namely, that the administrative system of the SSAH in Indonesia, which is related to health care services, lacks a sufficient quantity of essential care offices of reasonable quality. This is in addition to inadequate access to explicit medications and clinical supplies, the mistargeting of low-income and middle income populations, the issue of inappropriate behavior, and unforeseen weak data frameworks. ${ }^{4}$ These problems hamper the participation of the Indonesian people in NHI, meaning that full coverage is difficult to achieve.

Out of a population of approximately 267.3 million people, approximately 25.1 million Indonesians live below the poverty line. According to the data from March 2019, approximately $20.6 \%$ of the whole population is powerless to prevent falling into neediness, as their income barely drifts over the national poverty line. ${ }^{5}$ In the most recent decade, the prevalence of needy individuals in Indonesia declined from 19 to $11 \%$. However, the malnutrition rate shows no significant reduction. ${ }^{6}$ Indonesia has encountered a twofold ailment problem wherein the frequency of noncommunicable diseases (NCDs) is growing against a background of significant transmissible ailments, for example, tuberculosis and malaria.

There have been several previous studies regarding health insurance coverage. These studies have analyzed some of the determinants of insurance coverage, such as knowledge, ${ }^{8-12}$ cost $^{8,12}$ attitude and family support ${ }^{9,11,13,14}$, age ${ }^{14,15}$ region, history of chronic disease, economic status, residency, ${ }^{15}$ ability to pay, ${ }^{13,16}$ willingness to pay, average monthly expenses, ${ }^{13}$ risk aversion, amount of loss, income, ${ }^{16,17}$ information, ${ }^{11,18,19}$ religiosity, beliefs, ${ }^{18}$ education, ${ }^{10,15}$ income, ${ }^{10,11}$ motivation, intention, ${ }^{10}$ institutional policies, ${ }^{17}$ perception, ${ }^{10,19}$ social support, ${ }^{19}$ distance, and socialization. ${ }^{12,20}$ Therefore, this study presents new findings that determine the importance of NHI factors consisting of wealth quintile, residence, number of living children, marital status, current employment status and earnings.

The NHI aims to ensure that all Indonesian citizens have access to health services, especially the poor and near-poor. The development of the health service sector in Indonesia provides an opportunity for the Indonesian government to succeed in this program. In 2017, five provinces managed to achieve universal NHI coverage, which mostly included large cities in Indonesia, such as West Java (5.59\%), Central Java $(4.07 \%)$, Aceh $(4.01 \%)$, East Java $(3.87 \%)$, and North Sumatra $(2.91 \%))^{21}$ The larger the number of residents and the demographic location, the greater the achievement in NHI coverage.
In the eastern part of Indonesia, the NHI coverage is lower. Since 2014, when NHI was initiated, Indonesia has made steady progress, with approximately $133,423,653$ people becoming members of the NHI, but this is still far from Indonesia's total population of 255,18 million people. ${ }^{22,23}$ This is due to demographic factors and the fact that Indonesia consists of islands or regions, which causes the uneven distribution of NHI coverage. It has been assessed that $34 \%$ of the population is uncovered, and a large portion of these are individuals working in the informal sector, such as beggars, farmers, breeders, and day laborers. The growth in membership among this group has continuously slowed, dropping from $6.55 \%$ per month (2015) to $2.17 \%$ per month (2016). ${ }^{24}$ In light of these related issues, this investigation aims to understand the details of medical coverage inclusion and to deconstruct its determinant factors. The foundational attributes-for example, demographic characteristics, household characteristics, and financial condition-were selected for examination based on past investigations with certain adjustments due to information accessibility. This study aims to examine the determinants of health insurance coverage in Indonesia.

\section{Methods}

Study design

This study uses a cross-sectional design. Data were obtained from the secondary data of the Indonesian Demographic and Health Survey (IDHS) 2017. IDHS, in obtaining the data, worked closely with Indonesian stakeholders and collaborated with the Inner-City Fund (ICF) International.

\section{Setting}

This study uses data from IDHS 2017, which was conducted in December 2017. The study used the IDIR71FL (Indonesian Individual Recode phase 7) and IDMR71FL (Indonesian Men Recode phase 7) data sets. The data sets provide information about men and women within the age range of 15-54 years. For this study, the researchers combined the two data sets to obtain a total sample including both men and women. The sampling technique used by the IDHS was two-stage stratified cluster sampling, which includes selecting clusters from each stratum and a list of households in the selected clusters. Selected households were then interviewed by the IDHS. ${ }^{21}$ The total sample was 59,636 respondents. Then, the researchers weighted the data based on the provincial data in Indonesia and obtained 59,627. This is because the overall probability of selection for each household is not constant. The following describes how DHS weights are constructed and when they should be used. ${ }^{25}$ In this study, the inclusion criteria include being identified in the Individual Recode (women's data set) or Men's Recode (men's data set), being in the age range of 15-54 years old, and having been successfully interviewed for the IDHS 2017. The exclusion criterion was having missing data. After excluding observations with missing data, the total sample size was 39,580 (see Figure 1).

\section{Variables}

The independent variables in the study are age, education level, wealth quintile, residence, number of living children, marital 


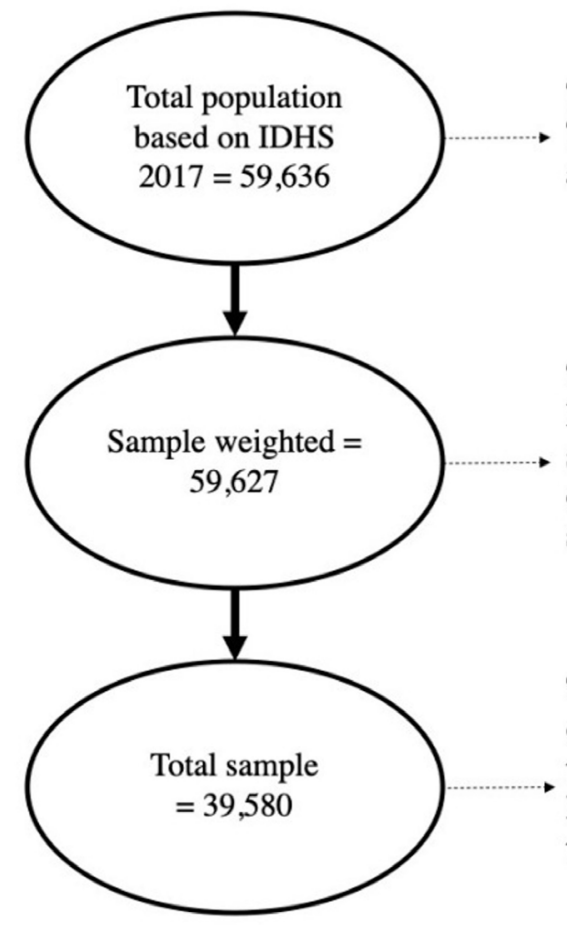

The total population based on IDHS 2017.

- The data combined the two data sets to obtain a spread across men (IDMR71FL) and women (IDIR71FL)

The data weighted it based on the provincial data in Indonesia. This is because the overall probability of selection of each household is not a constant. The following describes how DHS weights are constructed and when they should be used

The total sample was obtained after the missing data was excluded. In this study, the inclusion criteria identified from the Individual Recode (women's data set) and Men's Recode (men's data set) in the age range of 15 - 54 years that had been successfully interviewed based on IDHS 2017

Figure 1. Study Sample Selection.

status, current employment status and earnings. The age variable is divided into categories: 15-24 years, 25-34 years old, 35-49 years old, and 50-54 years old. ${ }^{26}$ Educational level is divided into four categories: high education, secondary education, primary education, and no education. ${ }^{27}$ Wealth quintiles were measured using principal component analysis (PCA). ${ }^{28}$ The categorization of the wealth quintiles includes richest, richer, middle, poorer, and poorest. ${ }^{29,30}$ The residence variable in this study contains the categories rural and urban. ${ }^{31}$ The variable measuring the number of children who are alive is categorized into three categories namely, 0-4, 5-9, and 10-14. ${ }^{21}$ The marital status variable is divided into six categories: single, married, with partner, widowed, divorced, and separated. ${ }^{21}$ The current employment status variable is divided into two categories, namely, "yes" (currently working) and "no" (not currently working). ${ }^{21}$ The variable for earnings is categorized into "not paid" if the respondent does not have an income and does not work. Meanwhile, the category of "paid" participants includes those who have an income in the form of cash only, cash and in-kind payments, or in-kind payments only. ${ }^{21}$

The dependent variable in this study is the coverage of the National Health Insurance, provided by the Indonesian government in the form of SSAH. The government states that all Indonesian citizens are required to become members of the NHI program with Indonesian Health Cards managed by the Indonesian government. ${ }^{32}$ The health insurance coverage variable is divided into two categories, namely, "yes" (has coverage) and "no" (does not have coverage). Respondents are said to have health insurance if at the time of the interview, they said that they have health insurance and could show a membership card. If at the time of the interview, there are family members who do not have health insurance, then they are not included in the category of having health insurance. ${ }^{21}$

\section{Research instruments}

This study uses the questionnaire from DHS Phase 7. The model in the DHS questionnaire emphasizes flexibility and basic indicators for the respondents. Health insurance coverage is available in the Women and Men Questionnaire Topics. ${ }^{33}$ Validity and reliability tests were conducted to decrease the rate of errors. The policies made by DHS for using the questionnaires were printed in the local language to help the respondents better understand the meaning of each question. ${ }^{34}$

\section{Data analysis}

To analyze the factors associated with health insurance coverage in Indonesia, the researchers used chi-squared analysis and binary logistics, conducted using Stata 16.1. Both variables were assessed using an OR with a $95 \%$ CI to examine the strength of the association and $\mathrm{p}<0.05$ was chosen to indicate statistical significance. We used the STATA version 16.1: "A Software resource for statistical analysis and presentation of graphics (Stata, RRID:SCR_012763)".

\section{Ethical considerations}

This study sought ethical approval from the Ministry of Health of Indonesia. The author was approved to use the following survey datasets obtained from ICF International as part of the Demographic Health Survey program with AuthLetter 
number 144520. DHS has policies requiring the use of questionnaires that have been translated and printed in all the major local languages in which interviews are expected to take place and requires signed informed consent. ${ }^{34}$ The dataset policy is available on the official website.

\section{Results}

The achievements in NHI coverage are mostly found in large cities in Indonesia, such as West Java, Central Java, Aceh, East Java, and North Sumatra. This is also due to the large number of residents and the demographic characteristics of the population that allow for the achievement of greater NHI coverage. However, the increasing NHI coverage is still accompanied by people who are not enrolled in the NHI. When viewed proportionately, Aceh Province has a higher level of NHI coverage than other provinces. Indonesia is divided into three parts, namely, Western, Central and Eastern Indonesia. Traveling east, NHI coverage decreases. This could be due to the central government's failure to make the NHI affordable. There are more provinces with a low level of NHI coverage than with a high level of coverage. Therefore, this should be a serious concern for the government (Figure 2).

The prevalence of health insurance coverage in Indonesia is $62.3 \%$. This still does not comply with government regulations that state that all Indonesian citizens are required to become members of the National Health Insurance-Indonesia Health Card program. The majority of respondents with health insurance were in the age range of 35-49 years (51.05\%). The majority of respondents had a secondary school education $(50.14 \%)$. Based on the wealth quintile data, many respondents were in the poorest category $(22.09 \%)$, and the majority of residences were urban $(52.69 \%)$. The data on the number of children who are alive showed that the majority were in the range $0-4(94.39 \%)$. The majority of respondents were married $(79.12 \%)$, currently working $(92.17 \%)$, and had earnings $(82.72 \%)$ (Table 1$)$.

The results of the bivariate analysis show that all variables have a significant relationship with health insurance coverage in Indonesia, with $\mathrm{p}<0.001$ (Table 2).

The multivariate analysis shows that age, education level, wealth quintile, marital status, and earnings have very significant relationships with health insurance coverage. The odds of respondents aged 15-24 years old being covered were 0.875 times lower than those of the comparison group. [AOR $=0.875 ; 95 \%$ $\mathrm{CI}=0.763-0.967]$. The odds of respondents with a secondary education level being covered were 0.437 times lower than those of the comparison group [AOR $=0.437 ; 95 \% \mathrm{CI}=0.410$ 0.466]. Respondents in a poorer wealth quintile had odds of having health insurance that were 0.762 times lower than those of the comparison group $[\mathrm{AOR}=0.762 ; 95 \% \mathrm{CI}=0.713$ 0.815]. Respondents who lived in a rural area had odds of being covered that were 0.782 times lower than those in urban areas $[\mathrm{AOR}=0.762 ; 95 \% \mathrm{CI}=0.713-0.815]$. Respondents with a

The Percentage of National Health Insurance Coverage in Indonesia Province, $\mathbf{n}=\mathbf{3 9 , 8 5 0}$

6

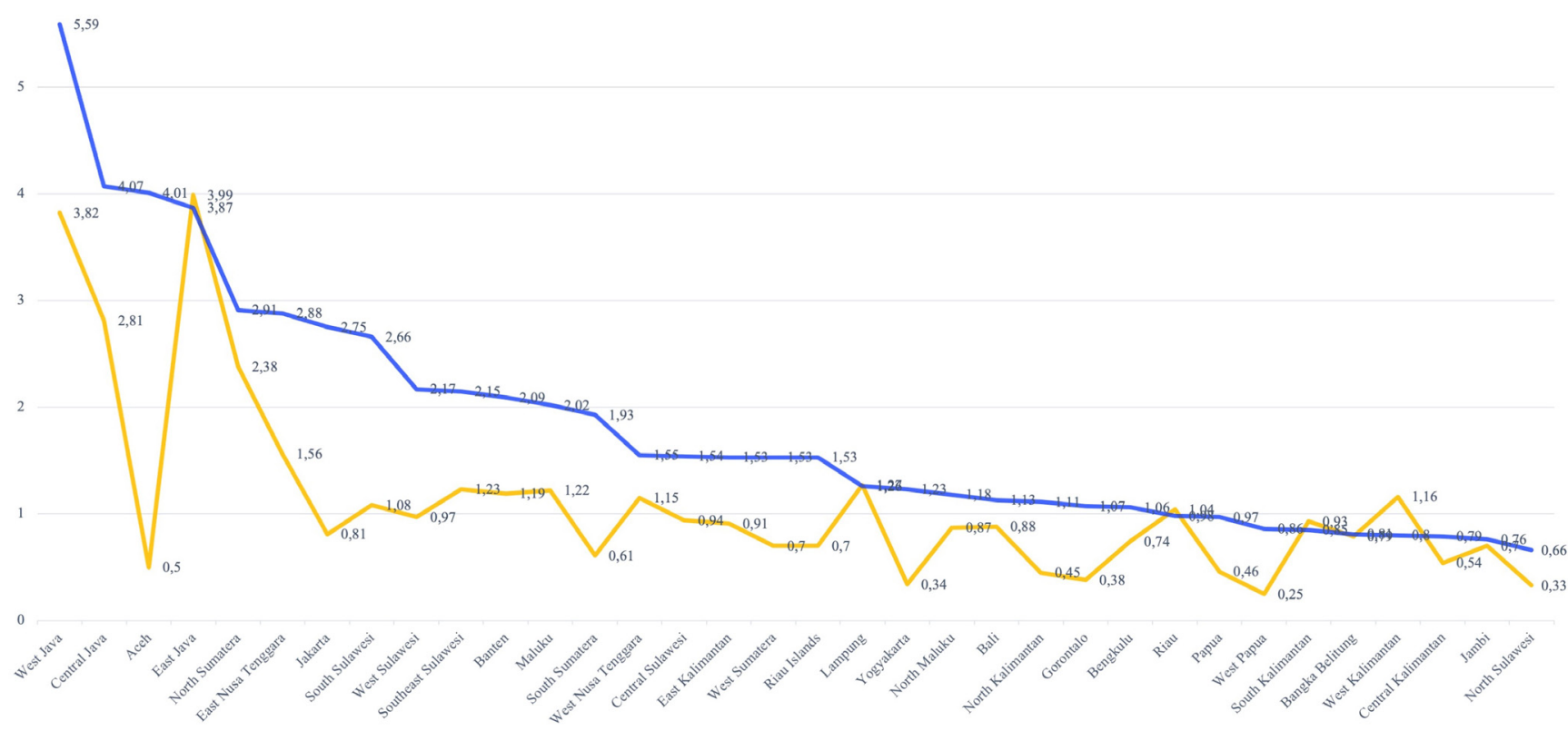

Figure 2. Distribution of National Health Insurance in Indonesia. 
Table 1. Respondent's characteristics

$(n=39,580)$.

\begin{tabular}{|c|c|c|}
\hline Characteristics & $\mathbf{n}$ & $\%$ \\
\hline $\begin{array}{l}\text { Health insurance coverage } \\
\text { No } \\
\text { Yes }\end{array}$ & $\begin{array}{l}14,922 \\
24,658\end{array}$ & $\begin{array}{l}37.7 \\
62.3\end{array}$ \\
\hline $\begin{array}{c}\text { Age (year) } \\
50-54 \\
35-49 \\
25-34 \\
15-24\end{array}$ & $\begin{array}{c}1,443 \\
20,207 \\
11,458 \\
6,472\end{array}$ & $\begin{array}{l}3.65 \\
51.05 \\
28.95 \\
16.35\end{array}$ \\
\hline $\begin{array}{l}\text { Education level } \\
\text { High education } \\
\text { Secondary education } \\
\text { Primary education } \\
\text { No education }\end{array}$ & $\begin{array}{c}7,898 \\
19,847 \\
10,970 \\
865\end{array}$ & $\begin{array}{c}19.95 \\
50.14 \\
27.72 \\
2.19\end{array}$ \\
\hline $\begin{array}{l}\text { Wealth quintile } \\
\text { Poorest } \\
\text { Poorer } \\
\text { Middle } \\
\text { Richer } \\
\text { Richest }\end{array}$ & $\begin{array}{l}8,745 \\
7,318 \\
7,508 \\
7,770 \\
8,239\end{array}$ & $\begin{array}{l}22.09 \\
18.49 \\
18.97 \\
19.63 \\
20.82\end{array}$ \\
\hline $\begin{array}{l}\text { Residence } \\
\text { Urban } \\
\text { Rural }\end{array}$ & $\begin{array}{l}20,856 \\
18,724\end{array}$ & $\begin{array}{l}52.69 \\
47.31\end{array}$ \\
\hline $\begin{array}{l}\text { The number of children } \\
\text { who are alive } \\
\begin{array}{l}10-14 \\
5-9 \\
0-4\end{array}\end{array}$ & $\begin{array}{c}28 \\
2,193 \\
37,359\end{array}$ & $\begin{array}{r}0.07 \\
5.54 \\
94.39\end{array}$ \\
\hline $\begin{array}{l}\text { Marital status } \\
\text { Single } \\
\text { Married } \\
\text { Partner } \\
\text { Widowed } \\
\text { Divorced } \\
\text { Separated }\end{array}$ & $\begin{array}{c}5,909 \\
31,316 \\
286 \\
784 \\
1,153 \\
132\end{array}$ & $\begin{array}{l}14.93 \\
79.12 \\
0.72 \\
1.98 \\
2.91 \\
0.33\end{array}$ \\
\hline $\begin{array}{l}\text { Currently working } \\
\text { No } \\
\text { Yes }\end{array}$ & $\begin{array}{c}3,100 \\
36,480\end{array}$ & $\begin{array}{c}7.83 \\
92.17\end{array}$ \\
\hline $\begin{array}{l}\text { Respondent earnings } \\
\text { No paid } \\
\text { Paid }\end{array}$ & $\begin{array}{c}6,840 \\
32,740\end{array}$ & $\begin{array}{l}17.28 \\
82.72\end{array}$ \\
\hline
\end{tabular}

marital status of divorced had odds of coverage that were 0.718 times lower than those of the comparison group [AOR $=0.718$; 95\% CI $=0.625-0.825]$. The odds of respondents who received paid earnings being covered were approximately 1.245 times higher than those of respondents who were not paid $[\mathrm{AOR}=1.245 ; 95 \% \mathrm{CI}=1.177-1.316]$. However, the number of children who are alive and the current employment status variables were not significantly related to health insurance coverage in Indonesia (Table 3).
Table 2. Bivariate analysis of the factors associated with health insurance coverage in Indonesia $(n=39,580)$.

\begin{tabular}{|c|c|c|c|c|c|}
\hline \multirow{3}{*}{ Variables } & \multicolumn{4}{|c|}{ Health Insurance } & \multirow{3}{*}{$\mathrm{X}^{2}$} \\
\hline & \multicolumn{2}{|c|}{ No } & \multicolumn{2}{|c|}{ Yes } & \\
\hline & $\mathbf{n}$ & $\%$ & $\mathbf{n}$ & $\%$ & \\
\hline $\begin{array}{c}\text { Age (year) } \\
50-54 \\
35-49 \\
25-34 \\
15-24\end{array}$ & $\begin{array}{c}532 \\
7,331 \\
4,484 \\
2,575\end{array}$ & $\begin{array}{c}1.34 \\
18.52 \\
11.33 \\
6.51\end{array}$ & $\begin{array}{c}911 \\
12,876 \\
6,974 \\
3,897\end{array}$ & $\begin{array}{c}2.30 \\
32.53 \\
17.62 \\
9.85\end{array}$ & $39.81^{\star \star *}$ \\
\hline $\begin{array}{l}\text { Education level } \\
\text { High } \\
\text { Secondary } \\
\text { Primary } \\
\text { No }\end{array}$ & $\begin{array}{l}1,722 \\
7,931 \\
4,895 \\
374\end{array}$ & $\begin{array}{c}4.35 \\
20.04 \\
12.37 \\
0.94\end{array}$ & $\begin{array}{c}6,176 \\
11,916 \\
6,075 \\
491\end{array}$ & $\begin{array}{c}15.60 \\
30.11 \\
15.35 \\
1.24\end{array}$ & $1100.0^{\star \star *}$ \\
\hline $\begin{array}{l}\text { Wealth quintile } \\
\text { Poorest } \\
\text { Poorer } \\
\text { Middle } \\
\text { Richer } \\
\text { Richest }\end{array}$ & $\begin{array}{l}3,418 \\
3,069 \\
3,227 \\
2,972 \\
2,236\end{array}$ & $\begin{array}{l}8.64 \\
7.75 \\
8.15 \\
7.51 \\
5.65\end{array}$ & $\begin{array}{l}5,327 \\
4,249 \\
4,281 \\
4,798 \\
6,003\end{array}$ & $\begin{array}{l}13.46 \\
10.74 \\
10.82 \\
12.12 \\
15.17\end{array}$ & 544.47 *** \\
\hline $\begin{array}{l}\text { Residence } \\
\text { Urban } \\
\text { Rural }\end{array}$ & $\begin{array}{l}7,090 \\
7,832\end{array}$ & $\begin{array}{l}17.91 \\
19.79\end{array}$ & $\begin{array}{l}13,766 \\
10,892\end{array}$ & $\begin{array}{l}34.78 \\
27.52\end{array}$ & $257.78^{\star \star *}$ \\
\hline $\begin{array}{l}\text { The number of } \\
\text { children who } \\
\text { are alive } \\
\begin{array}{l}10-14 \\
5-9 \\
0-4\end{array}\end{array}$ & $\begin{array}{c}6 \\
644 \\
14,272\end{array}$ & $\begin{array}{c}0.02 \\
1.63 \\
36.06\end{array}$ & $\begin{array}{c}22 \\
1,549 \\
23,087\end{array}$ & $\begin{array}{c}0.06 \\
3.91 \\
58.33\end{array}$ & $72.01 * \star *$ \\
\hline $\begin{array}{l}\text { Marital status } \\
\text { Single } \\
\text { Married } \\
\text { Partner } \\
\text { Widowed } \\
\text { Divorced } \\
\text { Separated }\end{array}$ & $\begin{array}{c}2,166 \\
11,736 \\
131 \\
291 \\
531 \\
67\end{array}$ & $\begin{array}{c}5.47 \\
29.65 \\
0.33 \\
0.74 \\
1.34 \\
0.17\end{array}$ & $\begin{array}{c}3,743 \\
19,580 \\
155 \\
493 \\
622 \\
65\end{array}$ & $\begin{array}{c}9.46 \\
49.47 \\
0.39 \\
1.25 \\
1.57 \\
0.16\end{array}$ & $55.36^{* \star *}$ \\
\hline $\begin{array}{l}\text { Currently } \\
\text { working } \\
\text { No } \\
\text { Yes }\end{array}$ & $\begin{array}{c}1,263 \\
13,659\end{array}$ & $\begin{array}{c}3.19 \\
34.51\end{array}$ & $\begin{array}{c}1,837 \\
22,821\end{array}$ & $\begin{array}{c}4.64 \\
57.66\end{array}$ & $13.24^{* \star *}$ \\
\hline $\begin{array}{l}\text { Respondent } \\
\text { earnings } \\
\text { Not paid } \\
\text { Paid }\end{array}$ & $\begin{array}{c}3,059 \\
11,863\end{array}$ & $\begin{array}{c}7.73 \\
29.97\end{array}$ & $\begin{array}{c}3,781 \\
20,877\end{array}$ & $\begin{array}{c}9.55 \\
52.75\end{array}$ & $173.56^{\star \star \star}$ \\
\hline
\end{tabular}

X2: chi-square; * $p<0.1 ; * * p<0.05$; *** $p<0.01$

\section{Discussion}

The NHI target of Indonesia is was that all Indonesians must be insured by $2019 .{ }^{35}$ It is important to know the factors associated with health insurance coverage so that a better and more appropriate policy can be developed. This study found 


\section{Table 3. Multivariate analysis of the factors associated with health insurance coverage in Indonesia $(n=39,580)$.}

\begin{tabular}{|c|c|c|c|}
\hline \multirow[t]{2}{*}{ Variables } & \multirow[t]{2}{*}{ AOR } & \multicolumn{2}{|c|}{$95 \%$ CI } \\
\hline & & Lower & Upper \\
\hline $\begin{array}{c}\text { Age (year) } \\
50-54 \\
35-49 \\
25-34 \\
15-24\end{array}$ & $\begin{array}{c}1.000 \\
1.094 \\
0.859 * \star \\
0.875^{\star *}\end{array}$ & $\begin{array}{l}0.976 \\
0.763 \\
0.765\end{array}$ & $\begin{array}{l}1.226 \\
0.967 \\
1.000\end{array}$ \\
\hline $\begin{array}{l}\text { Education level } \\
\text { High } \\
\text { Secondary } \\
\text { Primary } \\
\text { No }\end{array}$ & $\begin{array}{c}1.000 \\
0.437^{\star \star *} \\
0.338^{\star \star *} \\
0.330^{\star \star *}\end{array}$ & $\begin{array}{l}0.410 \\
0.313 \\
0.283\end{array}$ & $\begin{array}{l}0.466 \\
0.364 \\
0.386\end{array}$ \\
\hline $\begin{array}{l}\text { Wealth quintile } \\
\text { Poorest } \\
\text { Poorer } \\
\text { Middle } \\
\text { Richer } \\
\text { Richest }\end{array}$ & $\begin{array}{c}1.000 \\
0.762^{* * *} \\
0.672^{* * \star} \\
0.714^{\star * *} \\
0.935^{*}\end{array}$ & $\begin{array}{l}0.713 \\
0.628 \\
0.664 \\
0.863\end{array}$ & $\begin{array}{l}0.815 \\
0.720 \\
0.767 \\
1.013\end{array}$ \\
\hline $\begin{array}{l}\text { Residence } \\
\text { Urban } \\
\text { Rural }\end{array}$ & $\begin{array}{c}1.000 \\
0.782^{\star \star *}\end{array}$ & 0.745 & 0.821 \\
\hline $\begin{array}{l}\text { The number of } \\
\text { children who } \\
\text { are alive } \\
\begin{array}{l}10-14 \\
5-9 \\
0-4\end{array}\end{array}$ & $\begin{array}{c}1.000 \\
0.697 \\
0.426 *\end{array}$ & $\begin{array}{l}0.279 \\
0.171\end{array}$ & $\begin{array}{l}1.740 \\
1.061\end{array}$ \\
\hline $\begin{array}{l}\text { Marital status } \\
\text { Single } \\
\text { Married } \\
\text { Partner } \\
\text { Widowed } \\
\text { Divorced } \\
\text { Separated }\end{array}$ & $\begin{array}{c}1.000 \\
1.068^{*} \\
0.813 \\
1.028 \\
0.718^{\star * \star} \\
0.652^{* \star}\end{array}$ & $\begin{array}{l}0.988 \\
0.635 \\
0.869 \\
0.625 \\
0.458\end{array}$ & $\begin{array}{l}1.154 \\
1.040 \\
1.215 \\
0.825 \\
0.929\end{array}$ \\
\hline $\begin{array}{l}\text { Currently } \\
\text { working } \\
\text { No } \\
\text { Yes }\end{array}$ & $\begin{array}{l}1.000 \\
1.018\end{array}$ & 0.942 & 1.100 \\
\hline $\begin{array}{l}\text { Respondent } \\
\text { earnings } \\
\text { Not paid } \\
\text { Paid }\end{array}$ & $\begin{array}{c}1.000 \\
1.245^{\star \star *}\end{array}$ & 1.177 & 1.316 \\
\hline
\end{tabular}

that age, education level, wealth quintile, residence, marital status, and earnings type were associated with health insurance coverage.
Younger people are less likely to have health insurance. Old age increases the likelihood of health insurance enrollment and ownership. ${ }^{36-38}$ The older age groups were employed, enabling the purchase of insurance. ${ }^{39}$ Younger citizens are less likely to have health insurance because they have low access to both employer-sponsored and self-financed health insurance. These age groups were dominated by those who were still in school and depend on their parents economically. Membership schemes and insurance financing that involve all family members in the insurance program can be applied to increase insurance coverage at a younger age. The government can use this scheme as a form of health insurance membership recruitment.

Having only a secondary education level or lower significantly decreases the likelihood of being insured. Citizens with secondary education or above have an increased likelihood of health insurance enrollment ${ }^{36}$ and vice versa. ${ }^{38}$ A secondary or high education level for women is also associated with an increased rate of health insurance coverage. ${ }^{40}$ Education plays an important role in terms of imparting a level of knowledge and understanding about health insurance. Educated people are better at understanding the concept, benefits, and use of health insurance for the household, so they can make decisions about health insurance enrollment and understand its purpose of guarding them from sudden medical expenses. The government can promote health insurance programs in schools and companies. In addition to promotion at the school level targeting students and teachers, promotion at the company level targeting more varied levels of education: this way individuals with low to high levels of education can be easily reached.

The poorer, middle, richer, and richest wealth quintiles were less likely to have health insurance than poorest. The previous study stated that there was no significant association between wealth quintile and health insurance. ${ }^{41}$ Another study stated that the richest households were more likely to have health insurance. ${ }^{36,42,43}$ This could have occurred because the health insurance scheme in Indonesia is different from that of other countries. The poorest populations receive subsidized insurance to maintain and increase their health status, ${ }^{44}$ such as payment for health services in the emergency department, ${ }^{45}$ treatment for chronic illness, ${ }^{46}$ and treatment of the factors associated with the success of diabetes mellitus management. ${ }^{47}$ The poorest population's health insurance is fully paid for by the government. The other schemes are paid for by the health insurance members themselves. This scheme makes the poorest populations more likely to be listed as health insurance member, making their coverage rate higher. The ownership of private health insurance may be the reason why the wealthier are less likely to have national health insurance. A study showed that the amount of monthly income as part of wealth is related to the demand for private insurance in Indonesia. ${ }^{48}$ To increase the coverage of health insurance for other economic groups, the government can subsidize premiums for them. The government can work with companies to pass regulations stating that each company has an obligation to pay for 
insurance for its workers. This regulation can also protect the health of workers.

Rural households are less likely to have health insurance. ${ }^{40,43}$ The primary factor determining coverage for both the subsidized and contributory schemes in Indonesia is that citizens work and are urban residents of Java or Bali. ${ }^{49}$ The affordability of travel to the health insurance office can be another reason for low coverage. The existence of branch offices in each city can increase the reach of insurance agencies. An increase in the number of insurance agencies can make it easier for potential participants to register for NHI. The government can support the spreading of branch offices by providing good infrastructure and communication networks like telephone and internet. The role of the government in providing infrastructure greatly affects the existence of branch offices and customer service.

Those who are divorced are less likely to have health insurance. Women often lose their health insurance in the months after a divorce $^{50}$ and thus become uninsured..$^{51}$ Divorced women are more likely to experience socioeconomic disadvantages than married women. ${ }^{52}$ Divorced women lose their benefits in terms of health insurance as they are dropped from their husbands' health insurance policies. They also lose their dependent payments and are unable to afford other forms of coverage. Jobless divorced woman find it difficult to pay monthly insurance premiums, so they decide to drop their insurance coverage.

Being employed or paid is likely to be associated with having health insurance. ${ }^{43}$ Paid respondents are associated with the demand and possibility of having for health insurance enrollment. ${ }^{53,54}$ Paid employees obtain health insurance coverage from their employer. ${ }^{55}$ The stable income of a paid employee also makes it easier for them to choose the health insurance agency appropriate to their needs. They have more flexibility in choosing their insurance class and the amount of their monthly premium. Companies usually have their employees become members and pays the monthly premium. To maintain and increase the coverage of health insurance for groups of paid employees, the government can work with employers by requiring them to provide their workers with insurance, and the premium is paid by the company.

\section{Implications and limitations} Implications

The results of this study can be used as basic information for the Indonesian government when determining the policies necessary to achieve maximum insurance coverage for the welfare of the community. The government can collaborate with employers to register and pay insurance premiums for employees, improve infrastructure and communication networks so as to increase the reach of insurance agency branch offices, maintain payment schemes for the poorest population, and provide subsidized insurance payments for the poor and the poorer.

\section{Limitations}

This study used the data of men and women aged 15-54 years old. The government states that all residents must have health insurance. However, this study has not reviewed those under 15 years old or above 54 years old. In addition, other factors related to health insurance coverage can be studied for further information.

\section{Conclusion}

Health is an important asset for the future. Early protection is needed even when the body is healthy so that there is protection and health insurance when you get sick. NHI helps Indonesian people to get health insurance in the future by providing easy access to health facilities for everyone. NHI coverage is influenced by several factors including age, education level, wealth quintiles, residence, the number of children who are alive, marital status, current employment status, earnings, and health insurance status. These factors cause not everyone agrees or even wishes to join the NHI program. The role of the government is needed to ensure that the NHI program is a solution to support health and access to quality services for everyone.

\section{Data availability}

Indonesian Demographic Health Survey (IDHS) 2017 dataset is available online. Access to the dataset requires registration and is granted only for legitimate research purposes. A guide for how to apply for dataset access is available at: https://dhsprogram.com/data/Access-Instructions.cfm.
1. O'Connell T, Rasanathan $\mathrm{K}$, Chopra M: What does universal health coverage mean? Lancet. 2014; 383(9913): 277-279. PubMed Abstract | Publisher Full Text

2. Yusuf $E$, Awwaliyah I: The Implementation of Indonesian National Health Insurance Programme: How Satisfiedwerethe Insured Participants and the Healthcare Providers? J Consum Sci. 2018; 3(2): 27. Publisher Full Text

3. Puspa A: UHC Gagal Tercapai Perberat Keuangan BPJS. Media Indonesia. 2020.

Reference Source

4. Agustina $R$, Dartanto $T$, Sitompul $R$, et al.: Universal health coverage in Indonesia: concept, progress, and challenges. Lancet. 2019; 393(10166):
75-102.

PubMed Abstract | Publisher Full Text

5. The World Bank: Indonesia Overview. 2020. Reference Source

6. De Silva I, Sumarto S: Child Malnutrition in Indonesia: Can Education Sanitation and Healthcare Augment the Role of Income? J Int Dev. 2018; 30(5): 837-864 Publisher Full Text

7. Gani A, Budiharsana MP: The Consolidated Report on Indonesia Health Sector Review 2018. 2018; 56. Reference Source

8. Hapsari WD, Natassia K, Riniasih W: Analisis Faktor Yangmempengaruhi 
Minat Masyarakat Dalam Kepesertaan JKN-KIS Mandiri Di Desa Pandanharum Kabupaten Grobogan. Shine Cahaya Dunia Ners. 2019; 4(2): 19-26.

Publisher Full Text

9. Nadiyah H, Subirman S, Lusiana SD: Faktor-Faktor yang Berhubungan dengan Kepesertaan Program JKN di Wilayah Kerja Puskesmas Remaja Kota Samarinda.J Kebijak Kesehat Indones JKKI. 2017; 6(2): 66-72. Publisher Full Text

10. Puspitasari Y: Faktor Yang Mempengaruhi Partisipasi Kepesertaan Jaminan Kesehatan nasional Pada Pekerja Bukan Penerima Upah Di Desa Kasiyan Timur wilayah Kerja Puskesmas Kasiyan Kabupaten Jember Tahun 2016. Digit Respir Univ Jember. 2017. Reference Source

11. Purwaningsih SB: Faktor-Faktor Yang Berpengaruh Dengan Keikutsertaan Masyarakat Dalam Jaminan Kesehatan Nasional di Desa Tegalsari Kabupaten Ponorogo. 2016 Reference Source

12. Nelisma N, Afni N, Rosnawati R: Faktor-Faktor Yang Berhubungan Dengan Minat Masyarakat Dalam Kepesertaan BPJS Kesehatan Di Kelurahan Talise Valangguni. J Kolaboratif Sains. 2019; 1(1): 471-479. Reference Source

13. Pangestika V, Jati S, Sriatmi A: Faktor - Faktor Yang Berhubungan Dengan Kepesertaan Sektor Informal Dalam Bpjs Kesehatan Mandiri Di Kelurahan Poncol, Kecamatan Pekalongan Timur, Kota Pekalongan. J Kesehat Masy. 2017; 5(3): 39-48. Reference Source

14. Rahmuyati AL, Riyanto A, Halimah S: Faktor-Faktor Yang Berhubungan Dengan Kepesertaan Bpjs Mandiri Di Puskesmas Cipageran Tahun 2018. Pros Pertem Ilm Nas Penelit Pengabdi Masy (PINLITAMAS 1). 2018; 1(1): 5-8. Reference Source

15. Valentina R, Pujianto P: Faktor-Faktor yang Berhubungan dengan Pemanfaatan Layanan Rawat Jalan. Poltekita : Jurnal Ilmu Kesehatan. 2019; 13(1): 12-16 Publisher Full Text

16. Pohan LW: Faktor-Faktor yang Berhubungan dengan Keikutsertaan Masyarakat dalam Kepesertaan BPJS Mandiri di Wilayah Kerja Puskesmas Kotapinang. Repos Univ Sumatra Utara. 2018. Reference Source

17. Rahmawan MH: Faktor-Faktor Yang Mempengaruhi Keikutsertaan BPJS Kesehatan Pada Pekerja Sektor Informal Industri Tepung Tapioka Di Kecamatan Margoyoso Kabupaten Pati Tahun 2016. 2016. Reference Source

18. Sa'adah D: Analisis Faktor-Faktor Yang Mempengaruhi Partisipasi Dalam Program Asuransi BPJS Kesehatan (Studi Pada Masyarakat Dusun Giriloyo, Desa Wukirsari, Kec. Imogiri, Kab. Bantul). 2017. Reference Source

19. Rhoza N, Mahwati Y, Asih TN: Faktor-Faktor Yang Berhubungan Dengan Pengambilan (JKN) Di Kecamatan Babakan Ciparay Kota Bandung Tahun 2016. Jilm kesehat. 2016; 8(2): 80-84.

Reference Source

20. Atipah A: Faktor Yang Berpengaruh Terhadap Minat Masyarakat Dalam Keikutsertaan Program Jamkesda Di Desa Banjarlor Kecamatan Banjarharjo Kabupaten Brebes. Univ Negeri Semarang. 2016. Reference Source

21. Demographic Health Survey: Guide to DHS Statistics DHS-7. 2017. Reference Source

22. Badan Pusat Statistik: Profil Penduduk Indonesia Hasil SUPAS2015. 2015. Reference Source

23. BPJS Kesehatan: Executive Summary: Program Management Report and Financial Report on the JKN Program. 2014; 2015: 1-13.

24. Dartanto T: Universal Health Coverage in Indonesia: Informality, Fisca Risks and Fiscal Space for Financing UHC. 2017 Reference Source

25. Demographic Health Survey: Analyzing DHS Data. Demographic Helath Survey. 2019.

26. Health Ministry of Republic Indonesia: Age Classification Based on Category. Jakarta - Indonesia: Ditjen Yankes; 2009.

27. Kementrian Pendidikan dan Kebudayaan: UU No. 20 Tahun 2003 Tentang Sistem Pendidikan Nasional. Sistem Informasi Managemen Keuangan Kementerian Pendidikan dan Kebudayaan RI. Indonesia: Kementerian Pendidikan dan Kebudayaan; 2003; 1-38.

Reference Source

28. Vyas S, Kumaranayake L: Constructing socio-economic status indices: How to use principal components analysis. Health Policy Plan. 2006; 21(6): 459-468. PubMed Abstract | Publisher Full Text

29. Croft NT, Marshall AMJ, Allen CK: Guide to DHS Statistics (Version 2). Rockville, Maryland, USA: ICF International; 2018 Reference Source

30. Demographic Health Survey: Wealth Quintiles. USAID. 2018.

31. BPS: Peraturan Kepala Badan Pusat Statistik Nomor 37 Tahun 2010 Tentang Klasifikasi Perkotaan dan Perdesaan di Indonesia [Head of the Central Statistics Agency Regulation No. 37 Year 2010 About the Urban and Rural Classification in Indonesia]. Badan Pusat Statistik; 2010; 2015. Reference Source
32. BPJS Kesehatan: Badan Penyelenggara Jaminan Sosial Kesehatan. 2014.

33. Demographic Health Survey: DHS Model Questionnaire - Phase 7 (English, French). 2015.

Reference Source

34. ICF International: Survey Organization Manual for Demographic and Health Surveys. Calverton. Maryland: ICF International; 2012.

35. BPJS Kesehatan: Ringkasan Eksekutif Laporan Pengelolaan Program dan Laporan Keuangan Jaminan Sosial Kesehatan 2016. 2016.

36. Duku SKO: Differences in the determinants of health insurance enrolment among working-age adults in two regions in Ghana. BMC Health Serv Res. 2018; 18(1): 384

PubMed Abstract | Publisher Full Text | Free Full Text

37. Mwaura JW, Pongpanich S: Access to health care: The role of a community based health insurance in kenya. Pan Afr Med J. 2012; 12(1): 35. PubMed Abstract | Free Full Text

38. van der Wielen N, Falkingham J, Channon AA, et al.: Determinants of National Health Insurance enrolment in Ghana across the life course: Are the results consistent between surveys? Int J Equity Health. 2018; 17(1): 49. PubMed Abstract | Publisher Full Text | Free Full Text

39. Ritonga R: Kebutuhan Data Ketenagakerjaan Untuk Pembangunan Berkelanjutan. Jakarta - Indonesia; 2020. Reference Source

40. Mulenga JN, Bwalya BB, Gebremeskel Y: Demographic and socio-economic determinants of women's health insurance coverage in Zambia. Epidemiol Biostat Public Heal. 2017; 14(1): 1-9.

Publisher Full Text

41. Otieno PO, Wambiya EOA, Mohamed SF, et al.: Prevalence and factors associated with health insurance coverage in resource-poor urban settings in nairobi, Kenya: A cross-sectional study. BMJ Open. 2019; 9(12): e031543. PubMed Abstract | Publisher Full Text | Free Full Text

42. Sarpong N, Loag W, Fobil J, et al.: National health insurance coverage and socio-economic status in a rural district of Ghana. Trop Med Int Heal. 2010; 15(2): 191-197.

PubMed Abstract | Publisher Full Text

43. Kimani JK, Ettarh R, Warren C, et al.: Determinants of health insurance ownership among women in Kenya: Evidence from the 2008-09 Kenya demographic and health survey. Int J Equity Health. 2014; 13(1): 27. PubMed Abstract | Publisher Full Text | Free Full Text

44. Hamid AYS, Mustikasari MM, Panjaitan RU, et al.: Studi Fenomenologi: Kebijakan Pemerintah dalam Pemberian Jaminan Pemeliharaan Kesehatan Bagi Masyarakat Miskin yang Mengalami Masalah Kesehatan Jiwa. J Ners. 2011; 6(1): 100-111. Reference Source

45. Ahsan A, Deviantony F, Setyoadi S: Analysis of The Associated Factors of Boarding Time in Yellow Zone Patients in Emergency Department.J Ners. 2017; 12(2): 261-266. Publisher Full Text

46. Ahmad M, Rachmawaty R, Sjattar EL, et al.: Prolanis Implementation Effective to Control Fasting Blood Sugar, HbA1c and Total Cholesterol Levels in Patients With Type 2 Diabetes. J Ners. 2017; 12(1): 88-98. Publisher Full Text

47. Kusnanto K, Satriyaningarum NG, Pratiwi IN, et al.: Work stress and spirituality in diabetes mellitus self-management. Int J Psychosoc Rehabil. 2020; 24(7): 7641-7647. Publisher Full Text

48. Ashari MR, Nurhayani N: Permintaan (Demand) Masyarakat Terhadap Asuransi Kesehatan Di Public Demand on Health Insurance Utility in PT. Asuransi Jiwa InHealth Makassar. Media Kesehat Masy Indones. 2013; 9(1): 53-59.

Reference Source

49. Sari $\mathrm{B}$, Idris $\mathrm{H}$ : Determinant of independent national health insurance ownership in Indonesia. Malaysian J Public Heal Med. 2019; 19(2): 109-115. Publisher Full Text

50. Lavelle B, Smock PJ: Divorce and Women's Risk Of Health Insurance Loss. J Health Soc Behav. 2012; 53(4): 413-431. PubMed Abstract | Publisher Full Text | Free Full Text

51. Bernstein $A B$, Cohen RA, Brett KM, et al.: Marital status is associated with health insurance coverage for working-age women at all income levels, 2007. NCHS Data Brief. 2008; (11): 1-8. PubMed Abstract

52. Amato PR: Research on divorce: Continuing trends and new developments. J Marriage Fam. 2010; 72(3): 650-666. Publisher Full Text

53. Ying $\mathrm{XH}, \mathrm{Hu}$ TW, Ren J, et al.: Demand for Private Health Insurance in Chinese Urban Areas. Health Econ. 2007; 16(10): 1041-1050. PubMed Abstract | Publisher Full Text

54. Holahan J, Kenney G: Health Insurance Coverage of Young Adults: Issues and Broader Considerations. Timely Anal Immed Heal Policy Issues. 2008; 1-7. Reference Source

55. Mathur T, Paul UK, Prasad HN, et al.: Understanding perception and factors influencing private voluntary health insurance policy subscription in the Lucknow region. Int J Health Policy Manag. 2015; 4(2): 75-83. PubMed Abstract | Publisher Full Text | Free Full Text 


\section{Open Peer Review}

\section{Current Peer Review Status:}

\section{Version 1}

Reviewer Report 05 September 2022

https://doi.org/10.5256/f1000research.57086.r147665

(C) 2022 Bin Firdaus M. This is an open access peer review report distributed under the terms of the Creative Commons Attribution License, which permits unrestricted use, distribution, and reproduction in any medium, provided the original work is properly cited.

\section{Mohd Khairul Zul Hasymi Bin Firdaus}

Department of Medical Surgical Nursing, Kulliyyah (Faculty) of Nursing, International Islamic University Malaysia, Pahang, Malaysia

In general, this manuscript is interesting to read and contributes to a new body of knowledge. However, a little improvement may be required for this manuscript.

Methods:

1. Study design: I would suggest including 'retrospective' in the study design since the authors use existing data from the 2017 survey. But if I am wrong, kindly ignore this suggestion.

2. Variable:

It is not clear how the authors define the variables, i.e. education level. It is suggested to use a similar term for 'high educational' level with other variables so that it will represent the similar attributes of the category. Maybe can use as a tertiary education level? And for 'no education', it is suggested to change it into 'no formal education'. so that it may cover both those who might receive informal education and those who never enrolled in the schooling system.

For the categorization of the wealth quintile, it is not clear how the authors define the poorest, poorer, middle, richer and richest. It would be good if the authors can explain further the categorisation of these words. It will help the reader to better understand this manuscript.

3. Research instrument: The authors mentioned that reliability and validity were conducted. It would be great if the authors can include the reliability and validity values of the used research instruments in this manuscript.

In terms of language, I would suggest for the authors to submit it to a proofreader so that it will be better.

Other than that, it looks good. 
Is the work clearly and accurately presented and does it cite the current literature? Yes

Is the study design appropriate and is the work technically sound?

Yes

Are sufficient details of methods and analysis provided to allow replication by others? Yes

If applicable, is the statistical analysis and its interpretation appropriate? Yes

Are all the source data underlying the results available to ensure full reproducibility? Yes

Are the conclusions drawn adequately supported by the results?

Yes

Competing Interests: No competing interests were disclosed.

I confirm that I have read this submission and believe that I have an appropriate level of expertise to confirm that it is of an acceptable scientific standard.

Author Response 06 Sep 2022

Hidayat Arifin

Dear Reviewer

Thank your time to review our manuscript and for providing valuable comments and suggestions. We have pointed out all the issues.

Methods:

Study design: I would suggest including 'retrospective' in the study design since the authors use existing data from the 2017 survey. But if I am wrong, kindly ignore this suggestion.

Response: Thank you for your valuable suggestion. We have added the retrospective study design to the manuscript.

Variable:

It is not clear how the authors define the variables, i.e. education level. It is suggested to use a similar term for 'high educational' level with other variables so that it will represent the similar attributes of the category. Maybe can use as a tertiary education level? And for 'no education', it is suggested to change it into 'no formal education'. so that it may cover both those who might receive informal education and those who never enrolled in the schooling system. 
Response: Thank you for your suggestion. The division of education categories was based on the Statute of the Republic of Indonesia.

For the categorization of the wealth quintile, it is not clear how the authors define the poorest, poorer, middle, richer and richest. It would be good if the authors can explain further the categorization of these words. It will help the reader to better understand this manuscript.

Response: Thank you, we elaborated more information about wealth quintiles in the methods sections.

Research instrument: The authors mentioned that reliability and validity were conducted. It would be great if the authors can include the reliability and validity values of the used research instruments in this manuscript.

Response: Thank you, we have mentioned the reliability and validity values

In terms of language, I would suggest for the authors submit it to a proofreader so that it will be better.

Response: Thank you, the manuscript was proofread by a professional.

Competing Interests: Non

Reviewer Report 30 September 2021

https://doi.org/10.5256/f1000research.57086.r92728

(c) 2021 Lindayani L. This is an open access peer review report distributed under the terms of the Creative Commons Attribution License, which permits unrestricted use, distribution, and reproduction in any medium, provided the original work is properly cited.

\section{? Linlin Lindayani}

Sekolah Tinggi Ilmu Keperawatan PPNI Jawa Barat, Bandung, Indonesia

This study provides important information on highlighting the factors associated with health insurance coverage in Indonesia. Since full coverage in Indonesia is difficult to achieve, this information will be very meaningful for the Indonesian government to ensure that the coverage of $\mathrm{NHI}$ programs could be increased by designing interventions targeted to the significant factors affected by the NHI coverage.

However, I have few comments regarding this study:

\section{Abstract}

The authors need to briefly describe the factors that will be explored and their significance. 
Please add information about the two-stage stratified cluster sampling, stratified by what?

The government needs to pay attention to the characteristics and demographic conditions of the Indonesian population to be able to achieve maximum health insurance coverage. What kind of characteristics and demographic conditions of the Indonesian population? These should be pointed out according to the study findings.

\section{Introduction}

The logic is quite confusing to address the research gap.

There were some factors associated with low NHI coverage addressed from previous studies, such as belief and religiosity. Why did the authors not address these issues? Since Indonesia is one of the largest Muslim populations.

Maybe some argument to just only focus on the demographic data (not because of the available data provided in the DHS Questionnaire).

\section{Methods}

Since the data used IDHS 2017, researchers need justification that data from 2017 still has relevance with the current situations.

Validity and reliability tests were conducted to decrease the rate of errors. Please mention the value of validity and reliability.

\section{Results}

Be consistent in the tables - use two decimals in each table and also in the text.

\section{Discussion}

Important to highlight the low coverage of $\mathrm{NHI}$.

Is the work clearly and accurately presented and does it cite the current literature? Partly

Is the study design appropriate and is the work technically sound?

Yes

Are sufficient details of methods and analysis provided to allow replication by others? Yes

If applicable, is the statistical analysis and its interpretation appropriate?

Yes

Are all the source data underlying the results available to ensure full reproducibility? Yes

Are the conclusions drawn adequately supported by the results? Yes

Competing Interests: No competing interests were disclosed. 
Reviewer Expertise: Nursing technology, HIV, secondary analysis and review

I confirm that I have read this submission and believe that I have an appropriate level of expertise to confirm that it is of an acceptable scientific standard, however I have significant reservations, as outlined above.

Author Response 06 Sep 2022

Hidayat Arifin

Dear Reviewer,

Thank you for the valuable suggestions and comments. Here we pointed out the comments and make a revision as suggested.

\begin{abstract}
The authors need to briefly describe the factors that will be explored and their significance.

Response: Thank you, we have described the factors that are explored in the methods sections.

Please add information about the two-stage stratified cluster sampling, stratified by what?

Response: Thank you, it was stratified by household. Detailed information about the sampling technique was presented in the methods section.

The government needs to pay attention to the characteristics and demographic conditions of the Indonesian population to be able to achieve maximum health insurance coverage. What kind of characteristics and demographic conditions of the Indonesian population? These should be pointed out according to the study findings.
\end{abstract}

Response: Thank you for the suggestion and clarification. After review, we have made a revision in the conclusion section.

\title{
Introduction
}

There were some factors associated with low NHI coverage addressed in previous studies, such as belief and religiosity. Why did the authors not address these issues? Since Indonesia is one of the largest Muslim populations. Maybe some argument to just only focus on the demographic data (not because of the available data provided in the DHS Questionnaire).

Response: Thank you for your concerns. We faced limitations to perform belief and religiosity data in the analysis because the data in 2017 IDHS is not supported. Since the secondary data is from IDHS, all the information only presented demographic information. However, we put these concerns as a limitation. Thank you for your valuable suggestions.

\section{Methods}

Since the data used IDHS 2017, researchers need justification that data from 2017 still has relevance to the current situations. 
Response: Thank you, we have made sure that all the data presented has relevance to the current situations.

Validity and reliability tests were conducted to decrease the rate of errors. Please mention the value of validity and reliability.

Response: Thank you, we have presented the value of Cronbach alpha.

\section{Results}

Be consistent in the tables - use two decimals in each table and also in the text.

Response: Thank you, revised.

\section{Discussion}

Important to highlight the low coverage of NHI.

Response: Thank you for your valuable suggestion. We have elaborated information about the low coverage of NHI in the discussion section.

Competing Interests: None

The benefits of publishing with F1000Research:

- Your article is published within days, with no editorial bias

- You can publish traditional articles, null/negative results, case reports, data notes and more

- The peer review process is transparent and collaborative

- Your article is indexed in PubMed after passing peer review

- Dedicated customer support at every stage

For pre-submission enquiries, contact research@f1000.com 